\title{
The Effect of Power Distance, Moral Intensity, and Professional Commitment on Whistleblowing Decisions
}

\author{
Florencia Pangestu ${ }^{1}$, Dian Kartika Rahajeng ${ }^{2 *}$ \\ ${ }^{1}$ Department Accounting, Faculty of Economics and Business, Universitas Gadjah Mada, Yogyakarta, \\ 55281, Indonesia \\ 2 Department of Accounting, Faculty of Economics and Business, Universitas Gadjah Mada, \\ Yogyakarta, 55281, Indonesia
}

\begin{tabular}{|c|c|}
\hline ABSTRACT & ARTICLE INFO \\
\hline $\begin{array}{l}\text { Introduction/Main Objectives: Whistleblowing decisions are one of the } \\
\text { keys in fraud detection. Considering the rise of fraud cases in } \\
\text { organizations, this individual action has a significant impact on } \\
\text { organizational performance. Therefore, it is necessary to examine factors } \\
\text { that influence the whistleblowing decisions of individuals. Background } \\
\text { Problems: This study examines the effect of power distance, moral } \\
\text { intensity, and professional commitment on the whistleblowing decision } \\
\text { of undergraduate accounting students at the Faculty of Economics and } \\
\text { Business, Universitas Gadjah Mada (FEB UGM).Novelty: The novelty of } \\
\text { our research is we are filling the gap in previous studies by using students } \\
\text { as the population; most studies use employees (such as auditors) as the } \\
\text { main population. We use students because they form the next fraud- } \\
\text { fighting generation to enter the working environment. Therefore, their } \\
\text { understanding and perceptions of whistle blowing activities are crucial. } \\
\text { This research is considered to be the first micro-level analysis research in } \\
\text { the areas. Research Methods: We adopted the survey method and } \\
\text { analyzed it using a regression. We use purposive sampling on } 189 \text { under- } \\
\text { graduate students from the accounting department. Findings/Results: } \\
\text { Our findings indicate that power distance, moral intensity, and profes- } \\
\text { sional commitment simultaneously affect accounting students' } \\
\text { whistleblowing decisions. Power distance had a negative and significant } \\
\text { effect, meanwhile professional commitment had a positive and significant } \\
\text { effect and there was no significant effect of moral intensity toward the } \\
\text { whistleblowing. Conclusion: Having professional commitment is } \\
\text { essential for whistleblowing decision-making. It needs individual } \\
\text { awareness and professional ethics, as well as improvements to people's } \\
\text { morals and values. }\end{array}$ & $\begin{array}{l}\text { Article history: } \\
\text { Received in } 25 \text { March } \\
2020 \\
\text { Received in revised form } \\
2 \text { April } 2020 \\
\text { Received in revised form } \\
13 \text { April } 2020 \\
\text { Accepted } 4 \text { Mei } 2020 \\
\text { Keywords: } \\
\text { business ethics, moral } \\
\text { intensity, power distance, } \\
\text { professional commitment, } \\
\text { whistleblowing } \\
\text { JEL Code: } \\
\text { M42; D910 }\end{array}$ \\
\hline
\end{tabular}

\footnotetext{
* Corresponding Author at Department of Accounting, the Faculty of Economics and Business, Universitas Gadjah Mada, Jalan Socio Humaniora No. 1, Yogyakarta 55182, Indonesia.

E-mail address: florencia.pangestu@gmail.com (author\#1), dkrahajeng@ugm.ac.id (author\#2)
} 


\section{INTRODUCTION}

In the past few decades, the individual actions of one or several employees have had a significant impact on the image of certified public accounting (CPA) firms. The Enron and WorldCom fraud cases are examples where the responsible auditors failed to follow company policies and did not support the private parties who tried to correct the existing problems (Beenen \& Pinto, 2009; Verschoor, 2008). The rise of fraud cases in the accounting world indicates that the long-established forms of culture, policies, and practices of companies still cannot provide sufficient protection from adverse events caused by individuals or small groups of employees.

The best alternative to regulate the quality of organizational performance that focuses on problems related to principles, such as justice, honesty, or the economy, is through principled organizational dissent. Principled organizational dissent is an attempt by individuals in the workplace to protest or change the status quo of an organization because of a conscientious objection to a policy or practice that is running (Graham, 1986). There are two dissent forms identified by Hirschman (1970), namely exit and voice. The resignation of an employee interprets the exit. And the voice is interpreted by telling a concern that is owned by another party. Hirschman (1970)defines loyalty as rejecting the approach of exit (exit) and using voice (voice) as an attempt to correct errors that are thought to exist. Hirschman'sargument is in line with the preferences of companies, as they are happier when employees choose the loyalty or voice path, rather than resigning (exit).

According to Hirschman (1970), using someone's voice as a form of crossing opinion is generally referred to as whistleblowing, which can be directed both internally and externally, both directly speaking to parties who are in a position to follow up on reports or use the hotline reporting mechanism. Companies would prefer to have the opportunity to correct problems before they have to bear potentially higher costs when the regulator acts. Therefore, it is necessary to create a system where employees can conduct whistleblowing with a guarantee of personal security, while also protecting the company.

In general, research related to whistleblowing ethics emphasizes that employees should voice their protest within the company, before expressing it outside. It provides an opportunity for management to correct mistakes made by themselves or others in the organization (Young, 2006). However, there are still concerns that a hotline is considered to be less effective in detecting employee's deviant behavior.

The first factor that can affect the whistleblower's expectations of corrective or retaliatory action, and thus influence the whistleblowing decision, is power distance. Previous studies have had varied results regarding the relationship between power or offender status and whistleblowing (Rehg, Miceli, Near, \& Van Scotter, 2008). Apart from the limited research available, Taylor \& Curtis(2013), through their research, found that a relative hierarchical distance between violators and potential reporters (power distance) influences individual whistleblowing decisions.

The second factor suspected of being able to influence whistleblowing decisions is moral intensity. Jones (1991)states that ethical issues will arise when one's actions can harm or benefit others. This definition generally highlights that most decisions have a moral component. Bernardi, Banzhoff, Martino, \& Savasta (2011) state that students who conduct whistleblowing may show a higher intention to re-establish the purpose of whistleblowing. The study also found that students who used to cheat also had a low 
probability of whistleblowing. However, this finding is different from that stated by Banda \& Sholihin (2012), who, through his research, found that moral intensity did not influence individual decisions to conduct whistleblowing.

The last factor that might influence individual whistleblowing decisions is professional commitment. The Institute of Indonesian Chartered Accountants (2020) states that the principle of professional behavior requires that each professional accountant adheres to legal provisions, applicable regulations, and avoids practices that are known to professional accountants, or should be understood by them, which can reduce the public's trust in the profession. Elias (2006) states that in encouraging the development of accounting students' professional attitudes, it is necessary to design a good accounting education curriculum that is accompanied by a supportive environment. In his research, it was also found that professional commitment and social anticipation had a positive effect on whistleblowing decisions.

This study empirically tests whether power distance, moral intensity, and professional commitment influence the whistleblowing decisions of undergraduate accounting students at the Faculty of Economics and Business, Universitas Gadjah Mada (FEB UGM). The novelty of our research is we are filling the gap in previous studies by use students as the population; most studies have used employees (such as auditors) as the population.

We used undergraduate accounting students at FEB UGM for several reasons. First, they are the next fraud-fighting generation to enter the working environment. Therefore, their understanding and perceptions of whistleblowing activities are crucial. Secondly, immoral, illegal, or illegitimate practices by employees can have a drastically significant impact on the audit profession, as evidenced by the Arthur Andersen case. Accounting students are considered to be the future accountants, auditors, tax authorities, or fill similar positions in other financial fields, so capturing the student's current perspective is necessary to prepare further education systems, particularly in fraud literacy. Therefore, this study contributes to academics and businesses, such as universities in Indonesia and companies, to help them in gaining an understanding regarding the factors that can influence individual whistleblowing decisions. This study contributes to the whistleblowing literature by adding more perspectives (i.e. power distance, moral intensity, and professional commitment) to the pre-working population.

\section{LITERATURE REVIEW}

\section{Whistleblowing Decision}

Whistleblowing is an action by an employee, a former employee, or a member of an organization to report illegal violations by an organization that will adversely affect the public interest (Auerbach, 1961). Whistleblowing is defined as the disclosure by organizational members of unlawful, immoral, or illegitimate corporate actions or omissions to parties who can take action to correct the mistakes(Graham, Miceli, \& Near, 1992).

Whistleblowers are individuals who sound an alarm from within the organization in which they work, which aims to highlight violations or negligence that threatens the public interest (Bok, 1980). Miceli(1984) identified four categories of organizational members: 1) Individuals who did not observe errors. 2) Individuals who observed but did not report errors.3) Individuals who observed and reported errors only through internal channels.4) Individuals who observed and reported errors through internal and external channels. Marcia found that internal audit directors were less likely to conduct whistleblowing when they felt there was 
no encouragement to do so, both from a moral standpoint and in their professional role.

In general, accountants have a responsibility to the public to present financial statements that are fair; however, there may be some people who have different views regarding how this responsibility impacts on their obligation to conduct whistleblowing when they are aware of ethical violations. Situational and personal factors will influence whistleblowing decisions. Near, Rehg, Van Scotter, \& Miceli (2004) found that those who observed errors involving sexual harassment and mismanagement would be more likely to "blow the whistle" than those who observed problems of theft, discrimination, or safety. Graham et al. (1992) state that interpersonal traits, including gender, self-efficacy, and culture, can influence whistleblowing decisions.

In his research, Marcia P. Miceli \& Near (2005) suggested that employees are the most effective stakeholders to reduce unethical behavior in organizations. The reporter has many alternative channels of disclosure, including reporting to the employee's superiors, top management, company-provided hotlines, or reporting to external sources. Since the Sarbanes-Oxley Act requires that there be a mechanism in place to report fraud in public companies, there have been changes in the companies that implement it. One of them was expressed through research by Barnett et al. (1993), namely that organizations with internal disclosure policies and procedures, including whistleblowing, have experience a significant increase in the number of reports from employees. Marcia P. Miceli, Near, \& Schwenk (1991), who surveyed653 Director of Internal Auditing, found that respondents would be more likely to report incidents to external institutions, rather than through internal channels, when the event harmed their co-workers or the public.
Label \& Miethe (2011), in their study of auditors, also suggested that most auditors tended to prefer internal channels for conducting whistleblowing (75\%) compared to external channels (25\%). Most auditors also strongly oppose regulations that require whistleblowing. Gundlach, Douglas, \& Martinko (2003) suggested that reporters used a cost-benefit analysis that influenced whistleblowing decisions. Many reporters have had several negative consequences, including losing their jobs, threats of revenge and isolation (Chiu, 2003). Although there are negative consequences that must be borne by the reporter, for many people, whistleblowing is something they must do (Shawver \& Clements, 2008).

Following earlier studies (see Taylor \& Curtis, 2013), we considered power distance, moral intensity, and professional misconduct as our independent variables, because we find them to be significantly related to the likelihood of reporting incidents. Also, power distance moderates this effect in such a way that those who perceive this scenario to be of lower moral intensity are much more influenced by power distance than those who understand it to be of high moral strength are.

\section{Power Distance}

According to Taylor \& Curtis(2013), power distance is a relative measure related to the position distance between two parties, which in this study, is between prospective reporters and the perpetrators of unethical actions. Power distance can influence the decisions of potential reporters to conduct whistleblowing.

Taylor \& Curtis(2013) also stated that CPA firms generally have a well-defined and publicly recognized hierarchy structure. There is respect, even fear of the superiors, based on positions within the company. These feelings arise from the importance of the role of the boss in the 
evaluation and promotion process. In contrast, respect for peers is lower and is based more on social-psychological factors. Most research into whistleblowing makes assumptions about the power distance between prospective reporters and unethical actors. For example, Graham (1986) assumes the influence of power distance, while Trevino \& Victor(2018) manipulate contexts where there is no power distance, but a direct comparison of whistleblowing decisions to power distance between peers and superiors in an organization is rarely examined.

Most of the research on power distance aims to explain differences in behavior between cultures, and different perceptions of power distance from the same role in various countries. There are two power distance-related studies that also discuss ethics and public accounting, but offer conflicting results. Smith \& Hume (2005) found that individualism is a factor that has a more substantial influence on the perceptions of public accountants' ethics compared to power distance. On the other hand, Cohen present evidence of a systematic relationship between ethical sensitivity and power distance for accounting ethics issues. Although the existing research is still rare, and the results reach different conclusions, this study assumes that power distance influences ethical decisionmaking, especially whistleblowing.

In the accounting literature, Lord \& DeZoort (2001) discuss several types of social pressures that can influence the professional judgment and decision making of auditors. They includes compliance pressure, which causes people to do what is requested regardless of the applicant's position; obedience pressure, which causes a person to submit to authority; and conformity or peer pressure, which results in the desire to think and behave consistently with the group's members. These three pressures have the potential to influence an auditor to take unethical actions, and also influence the auditor's decision to conduct whistleblowing. However, compliance and conformity can affect reporting based explicitly on the relationship between the prospective reporters and offenders.

In a report on fraud in public organizations, written by Deloitte \&Touche (2007), it is said that employees often observe mistakes made by their supervisors. The same study found that 40 percent of employees would immediately notify the supervisor and nearly 20 percent of respondents decided not to do anything. Finn (1995) discusses power distance in his whistleblowing model. He states that the risk of retaliation (including job loss) is the highest risk of whistleblowing and can reduce the likelihood of whistleblowing.

When an auditor observes a peer who takes an unethical action, conformity pressure can reduce the intention to blow the whistle. Trevino \& Victor(2018) state that reporting one's peers maybe even more difficult than reporting superiors. But in a comprehensive study of the behavior of whistleblowers, Mesmer-Magnus \& Viswesvaran (2005) found that the closer the relationship is between the prospective reporter and the perpetrator, both in their interpersonal or organizational structure, the higher the intention is to blow the whistle.

Based on existing research related to the perception of strength that has been formed culturally, compliance pressure and conformity to the high-power distance, the proposed hypothesis is as follows:

H1: Power distance has a negative effect on the whistleblowing decision, where prospective reporters will be more likely to blow the whistle on peers than on superiors.

\section{Moral Intensity}

Ethical decisions are defined as actions or legal decisions that are accepted by society from a 
moral side, and against illegal and morally unacceptable decisions, thus concluding that ethical and virtuous actions are things that can replace each other (Jones, 1991). He also stated that moral intensity influences the decisionmaking process carried out by an individual, with the level of moral intensity varying from one issue to another. Moral intensity comes from the normative argument of philosophers, who base moral responsibility on the kind of goodness (or crime) involved in decisions, the urgency of the situation, the probability of the effect, the extent of moral influence on events, and the availability of other possible alternatives.

Previous studies related to whistleblowing have found that moral intensity is a powerful determinant of the whistleblowing decision. For example, Singer, Mitchell, \& Turner (1998) examined the effect of moral intensity in a study of the whistleblowing intentions of $53 \mathrm{em}$ ployees who believed that food quality could be sacrificed. This study found that the magnitude of the consequences, the possible consequences to be borne and perceived empathy were significant factors in determining the decision to blow the whistle or not.

In a study of audit training students, Brennan \& Kelly (2007) suggested that the students would be more likely to undertake whistleblowing in organizations that have a formal reporting structure. In this study, the legal structure was said to provide further confidence to prospective reporters that whistleblowing actions would not hurt the reporter's career. Elias (2008) showed that students in the auditing class, who have a higher perception of financial responsibility to the public, will be more likely to do whistleblowing. In a study of accounting students, Shawver (2008) found that accounting students were more likely to do whistleblowing in situations involving higher materiality levels and when the security of their status was guaranteed to be secure.

Whereas, in terms of research related to accountants and professional human resources, Lovell (2002) found that those who are aware of unethical or illegal actions have significant worries about their job prospects when conducting whistleblowing. Clements \& Shawver (2009) and Shawver \& Shawver (2008) state that although accountants can recognize unethical situations, they tend not to do whistleblowing. This study examines the effects of two factors that are considered by accountants when deciding to undertake whistleblowing, namely the potential loss as a whole and the pressure to be faced. Based on the explanation above, the second hypothesis is:

$\mathrm{H} 2$ : Moral intensity has a positive effect on the whistleblowing decision.

\section{Professional Commitment}

Professional commitment has a secure attachment to devotion to one's professional career, identification with professions, and acceptance of goals and professional ethics (Sorensen \& Sorensen, 1974). In the accounting literature, professional commitment refers to the trust and recognition of goals as well as the values of the profession, the willingness to make great efforts in the name of the profession, and the desire to maintain membership status in the profession (Aranya, Barak, \& Amernic, 1981).

Aranya, Barak, \& Amernic (1981) suggest that along with increasing professional commitment, the sensitivity to problems related to professional ethics will also increase. Likewise, Lord \& DeZoort (2001) argue that increased professional commitment should lead the auditor toward actions that prioritize the public interest, and stay away from behavior that has the potential to damage the image of the profession. However, empirical studies related to the relationship between auditors' professional 
commitment and evaluation and ethical decisions have mixed results (Elias, 2008). As an illustration, Shaub, Finn, \& Munter (1993) state that there is no relationship between professional commitment and an auditor's ability to identify ethical issues. On the other hand, Jeffrey \& Weatherholt (1996) and Jeffrey, Weatherholt, \& Lo (1996) found a positive relationship of professional commitment to compliance for auditors. Taylor \& Curtis (2010) found a positive correlation between professional commitment and the intention of an auditor to blow the whistle. Still, he did not find a relationship between professional commitment and persistence in reporting intentions. Based on previous findings, the third hypothesis to be examined is:

H3: Professional commitment has a positive effect on the whistleblowing decision.

\section{Research Framework}

The framework of this study illustrates the model that was examined and explains the relationship between the research variables. The variables studied include:

1. Independent variables: power distance, moral intensity, and professional commitment

2. Dependent variable: decision to undertake whistleblowing

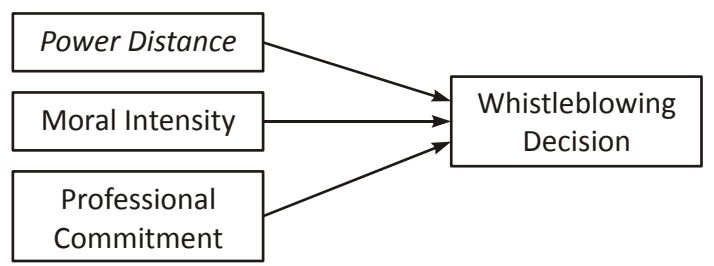

Figure 1. Research framework

\section{RESEARCH METHODOLOGY}

The purpose of this study was to determine the effect of power distance, moral intensity, and professional commitment on the whistleblowing decisions of undergraduate accounting students at FEB UGM. The approach used in this study was a quantitative approach, which is a type of research that aims to describe a phenomenon that occurs in a population and explain the relationship between the existing variables (Cooper \& Schindler, 2014). The research method used was a survey through questionnaires distributed to the respondents, to achieve the objective's results of getting answers that can generalize a population (Polit \& Beck, 2010). This study also used statistical analysis by testing the causal hypotheses between the dependent variables independently.

\section{Sampling Method, Sample, and Population}

The population taken consisted of all the active undergraduate students in the FEB UGM Accounting Program who comprise the class of 2015-2016. This population is assumed to understand accounting standards and practices and will be faced with ethical dilemmas when entering the workforce later. The number of active undergraduate students in the FEB UGM Accounting Program (2015-2016 class) is 306. The active undergraduate students of the Accounting Program FEB UGM are scattered and illustrated in the following table:

Table 1. Distribution of active undergraduate students of accounting study program FEB UGM (class of 2015-2016)

\begin{tabular}{ccccc}
\hline Class & Semester & Regular & IUP & Total \\
\hline 2015 & 8 & 158 & 55 & 213 \\
2016 & 6 & 146 & 47 & 193 \\
\hline \multicolumn{1}{l}{} \\
\hline
\end{tabular}

However, not all the population would participate in this study. The sampling method in this study was purposive sampling. From this population, research samples were selected that met several criteria relevant to the focus of this study. The requirements for obtaining the sample 
of this study were active undergraduate students of the Accounting Program FEB UGM who are taking and/or had taken Intermediate Financial Accounting 1, Business Ethics and Profession and Auditing 1 courses. The reason behind these criteria was because the students who took those courses were assumed to have knowledge and understanding regarding the basic accounting standards and practices, the professional commitment of accountants, whistleblowing systems, the professional code of ethics for accountants, and the types of actions that are considered unethical and are forms of fraud, so they can understand the scenario in the questionnaire correctly.

\section{Data Collection}

Data collection is done through survey methods, namely by distributing the questionnaires to prospective research respondents online, using Google Form, which can be shared through the online communication application, LINE. Data obtained from potential respondents were the primary data, without any manipulation by the researchers.

\section{Research Instruments}

The questionnaire is divided into five parts, including:

1. The first part is a question related to the profile of the respondents, among others regarding gender, class, and whether they have taken the required courses above.

2. The second part measures how likely the respondent would be to undertake whistleblowing with two different scenarios. In both situations, the respondents were asked to estimate the intention to do whistleblowing when the perpetrator was a peer and when the perpetrator was their superior.

3. The third part measures the moral intensity of respondents through questions to measure the level of seriousness of the violation in the case and measures the level of responsibility of the respondent to participate in whistleblowing when faced with the situation presented.

4. The fourth section measures the respondent's professional commitment through questions related to their general views or beliefs.

The complete answers to each part of the questionnaire were examined, and if there were parts that had not been answered or did not meet the criteria submitted, then that respondent's answerswere not included in the subsequent data processing and analysis.

\section{Variable Operational Definitions}

\subsection{Power distance}

Power distance can be defined as a level of uneven distribution of power and wealth. In low power distance societies, there is a higher level of dependence between superiors and subordinates, and people with positions, ranks, and status tend not to be distinguished (Hofstede, 1993).Goodwin \& Goodwin (1999) suggest that power distance has a significant influence on ethical implications. High power distance can cause an individual not to question the unethical behavior of a superior. In contrast, low power distance is more likely to encourage individuals to follow up on such unethical behavior, one means of which is with whistleblowing.

\subsection{Moral intensity}

Jones (1991)described moral intensity as a multidimensional construction that captures how far the moral importance of a problem reaches, and can be identified by six dimensions. Moral intensity can affect one's decision-making process, and the level of moral intensity varies from one issue to another. Jones argued that the higher the moral intensity of a problem, the less 
likely someone is to engage in unethical behavior.

\subsection{Professional commitment}

Professional commitment is the relative strength of an individual's ability to identify and engage in a profession, including its beliefs and the acceptance of its goals and professional values (Aranya \& Ferris, 1984).Lee, Carswell, \& Allen (2000) identified four reasons for understanding professional commitment. First, one's career represents one's main focus in life. Second, because professional commitment affects retention, it has a significant influence on human resource management. Third, because professional expertise develops from work experience, so work performance can be associated with professional commitment. This is relevant for accountants whose expertise comes from extensive experience. Finally, a further study of professional commitment can lead to an understanding of how individuals develop and integrate commitments inside and outside their workplace.

\subsection{Whistleblowing decision}

Hunt \& Vitell (1986) say that the intention of an individual to act can be measured by asking questions about the possibility that someone will take such action. The decision or intention to conduct whistleblowing will be measured by understanding the intention and probability of the response to be made by the respondent, based on the question scenario presented.

\section{Data Analysis Techniques}

\subsection{Descriptive statistical test}

Descriptive statistical tests aim to analyze and present a general overview of the data collected. The results of the descriptive statistical test consist of average, minimum, maximum, and standard deviation values.

\subsection{Validity and reliability test}

A validity test aims to find out and ensure that the research instruments used can measure the concept of the research correctly before the data analysis is carried out (Sekaran \& Bougie, 2013). Testing the validity of the questionnaire instrument of this research was done using the Bivariate Pearson Correlation Coefficient method, where the tool is declared valid if the calculated $r$-value is higher than the $r$ table value.

A reliability test is a measurement that aims to determine the stability and consistency of the instruments that measure the concept of the research (Sekaran \& Bougie, 2013). The reliability test also serves to test the accuracy and consistency of the respondents' answers from time to time. The method used for the reliability test in this study is Cronbach's alpha, where the higher the level of the coefficient, the better the instrument is said to be. A variable can be declared reliable when its Cronbach's alpha value is above 0.6 and is said to be good if more than 0.8 (Sekaran \& Bougie, 2013).

\subsection{Classic assumptions test}

The classic assumption test is a test that aims to determine whether the applied regression estimation results are free from bias, which has the potential to make the results obtained invalid. If the regression results, according to the classic assumption test, are invalid, then the results cannot be used as a basis for testing the hypotheses or drawing conclusions (Ghozali, 2018). The classic assumption test is divided into three tests, including a normality test, a heteroscedasticity test, and a multicollinearity test. 


\section{Hypothesis test}

\subsection{Multiple linear regression}

A multiple linear regression is an analytical method that aims to determine the effect of one dependent variable on several independent variables (Ghozali, 2018). In this study, multiple linear regression tests analyzed the influence of power distance, moral intensity, and professional commitment on an individual's whistleblowing decision. Below is the multiple linear regression model used in this study:

$$
\mathrm{Y}=\alpha+\beta 1 \mathrm{X} 1+\beta 2 \mathrm{X} 2+\beta 3 \mathrm{X} 3+\mathrm{e}
$$

Description: $\mathrm{Y}=$ Whistleblowing decision

$$
\begin{aligned}
& \alpha=\text { Constant } \\
& \beta=\text { Regression coefficient } \\
& \mathrm{X} 1=\text { Power distance } \\
& \mathrm{X} 2=\text { Moral intensity } \\
& \mathrm{X} 3=\text { Professional commitment } \\
& \mathrm{e}=\text { Error }
\end{aligned}
$$

\subsection{Test the coefficient of determination}

The test of the coefficient of determination is a test that aims to measure the variation in the dependent variable that can be explained by the independent variable (Ghozali, 2018). The coefficient of determination has a range from zero to one. When the value of the determination coefficient approaches one, the better is the ability of the independent variable to explain the overall variation of the dependent variable. If the value of the coefficient of determination is close to zero, this indicates that the independent variable is increasingly unable to explain the overall variation of the dependent variable (Ghozali, 2018).

\subsection{F-Test}

This F-test was carried out to examine the effect of all the independent variables together on the dependent variable (Ghozali, 2018). The research's regression model is considered good, or the independent variable is simultaneously considered to have a significant influence on the dependent variable so that Ho can be rejected and the alternative hypothesis accepted, if the calculated $F$ value at the 0.05 degree of confidence is greater than the $\mathrm{F}$ table value (Ghozali,2018).

\subsection{T-test}

The t-test is a test that aims to determine how much influence an independent variable has to explain the variation in the dependent variable (Ghozali, 2018). The independent variable in the research's regression model is said to not influence the dependent variable if the calculated $\mathrm{t}$ value is smaller than the $\mathrm{t}$ table value, and is said to have no significant influence on the dependent variable if the significance value is greater than 0.05 (Ghozali, 2018).

\section{RESULT AND DISCUSSION}

\section{Research Respondents}

FEB UGM undergraduate accounting students in the class of 2015 and 2016 were the respondents in this study. The questionnaires were distributed to the respondents online, between June 12 and June26, 2019. There were 210 questionnaires distributed and 194 questionnaires returned (92.38\%).

Five questionnaires could not be analyzed because they did not meet the requirements, so 189 were finally submitted for analysis.

\section{Profile of Respondents}

The profile of the respondents is described through the distribution of their gender and entry force. Figure 2 gives an overview of the distribution of the respondents by their gender, with 117 females (62\%), and 72 males (38\%), while based on the force, there are 126 people (67\%) from the class of 2015 class and 63 people (33\%) from the 2016 class. 


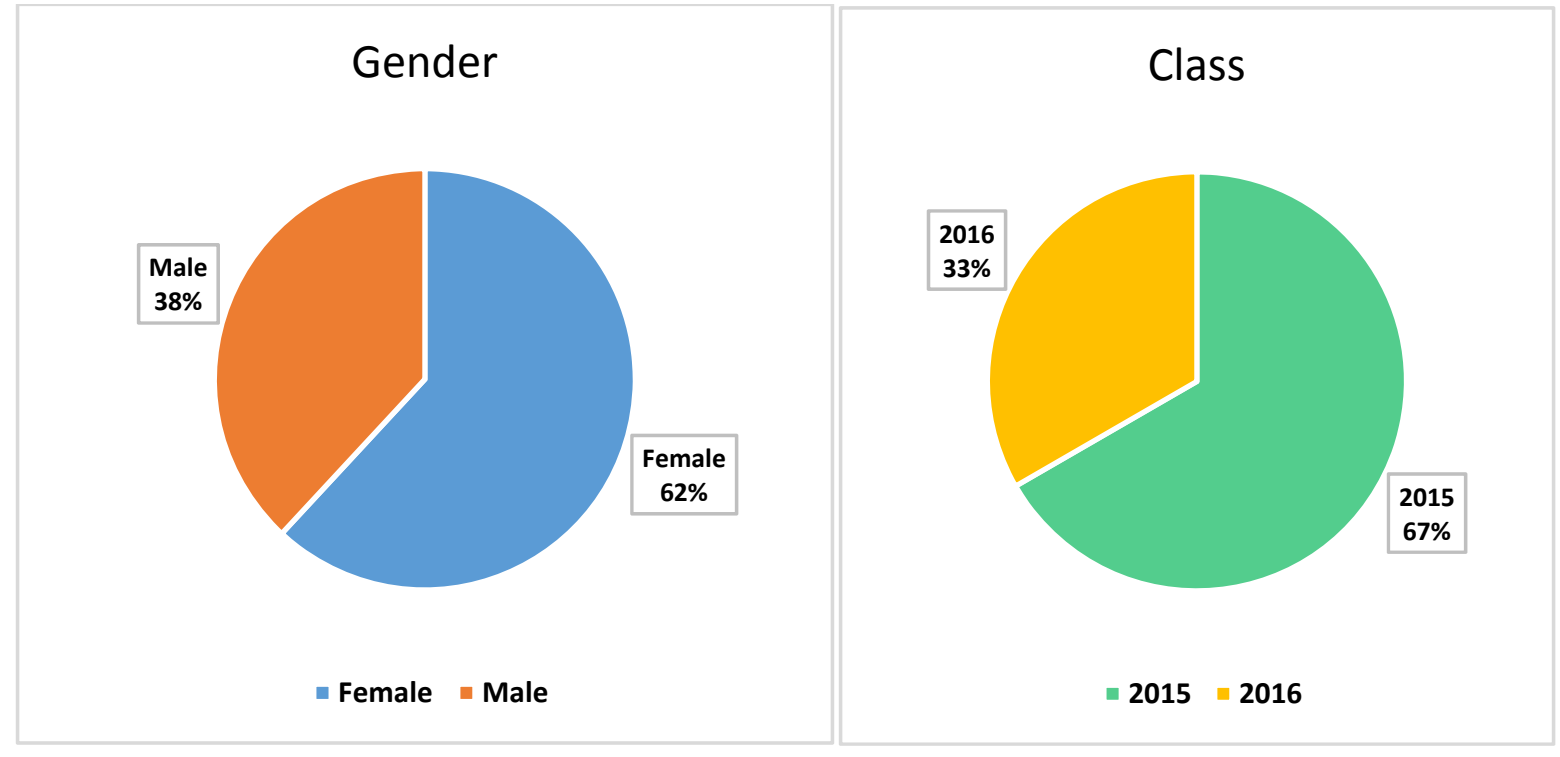

Figure 2. Profile of respondents based on gender and class

\section{Descriptive Statistics}

A descriptive statistical analysis is used to know the description of each research data variable, which includes the amount of data studied, and the minimum, maximum, average, and standard deviation values. The results of the descriptive statistical analysis of this study are described in the table below.

The variables for moral intensity (MI) and whistleblowing decisions (WB) have a minimum value of 2.00 and 10.00 for the maximum value, while for the professional commitment variable (PC), the minimum and maximum values are 6.00 and 23.00. From the minimum value of each variable, it can be seen that for the MI, PC, and WB variables, each of them had respondents who chose answer 1 (strongly disagree) on the Likert scale provided. Whereas, based on the maximum value presented, it is known that, for the PC variable only, there were no respondents who choose answer 5 (strongly agree).

Table 2. The results of the descriptive test for power distance variables

\begin{tabular}{cccccc}
\hline & Frequency & Percentage & $\begin{array}{c}\text { Validity } \\
\text { Percentage }\end{array}$ & $\begin{array}{c}\text { Cumulative } \\
\text { Percentage }\end{array}$ \\
\hline \multirow{3}{*}{ Valid } & 0.00 & 95 & 50.3 & 50.3 & 50.3 \\
& 1.00 & 94 & 49.7 & 49.7 & 100.0 \\
& Total & 189 & 100.0 & 100.0 & \\
\hline
\end{tabular}

Table 3. Descriptive statistics results

\begin{tabular}{ccccccc}
\hline No. & \multicolumn{1}{c}{ Variable } & N & Minimum & Maximum & Mean & St. Deviation \\
\hline 1. & Moral Intensity & 189 & 2.00 & 10.00 & 7.1905 & 2.54653 \\
2. & Professional Commitment & 189 & 6.00 & 23.00 & 13.1746 & 4.94611 \\
3. & Whistleblowing Decision & 189 & 2.00 & 10.00 & 6.5979 & 2.32864 \\
\hline
\end{tabular}


Through the average value of each variable, it is known that the order of the largest is MI with 7.1905, then second is WB with 6.5979, and the smallest is 13.1746. This average value shows that in the MI variable, the average respondent selected answer 4 (agree), while the WB variable is answer 3 (neutral), and in the PC variable, the average respondent picked answer 2 (disagree). Through the average value of the variables, it is known that respondents tended to agree on statements regarding moral intensity.

\section{Data Quality Test}

The researcher tested the quality of the data in this study with a pilot test. The pilot test was conducted with five respondents. The results of the pilot test illustrated that all the instrument items in this study met the requirements for validity and reliability. Through Tables 4 to 5 , it can be seen that all the research instruments for all the variables of this study can be declared valid, because the calculated r-value is greater than the $r$ table value. Whereas for the power distance variable, it could not be tested because it used a dummy variable, i.e., zero will be used to describe the position of the peers and one is superior.

\section{Moral Intensity}

Table 4. Validity test for Moral Intensity

\begin{tabular}{ccc}
\hline Item & r value & Description \\
\hline MI1 & 0.947 & Valid \\
MI2 & 0.948 & Valid \\
\hline
\end{tabular}

2. Professional Commitment

Table 5. Validity test for Professional Commitment

\begin{tabular}{ccc}
\hline Item & rvalue & Description \\
\hline PC1 & 0.869 & Valid \\
PC2 & 0.884 & Valid \\
PC3 & 0.844 & Valid \\
PC4 & 0.862 & Valid \\
PC5 & 0.876 & Valid \\
PC6 & 0.888 & Valid \\
\hline
\end{tabular}

3. Whistleblowing Decision

Table 6. Validity test for Whistleblowing Decision

\begin{tabular}{ccc}
\hline Item & r value & Description \\
\hline WB1 & 0.945 & Valid \\
WB2 & 0.956 & Valid \\
\hline
\end{tabular}

Table 7. Reliability tests

\begin{tabular}{ccc}
\hline Variable & Cronbach's alpha & Description \\
\hline MI & 0.887 & Reliable \\
PC & 0.936 & Reliable \\
WB & 0.891 & Reliable \\
\hline
\end{tabular}

From the results of the tests conducted, the three instrument variables of this study can be said to be reliable, because the value of Cronbach's alpha is greater than 0.60 .

\section{Classical Assumptions Test}

Classic assumption testing results showed that the model had fulfilled all the classical assumptions of multicollinearity, autocorrelation and heteroscedasticity, as required by the multiple linear regression method ${ }^{1}$.

\section{Hypotheses Test}

After testing the quality of the data, the next step was to check the research hypotheses by applying the tested coefficient of determination, F-test, and t-test.

\subsection{Coefficient of determination test}

This study has three independent variables. Therefore, the adjusted $\mathrm{R}$ square value is the coefficient of determination used. Table 8 . will explain the results of the tested coefficient of determination:

\footnotetext{
${ }^{1}$ Classical assumptions test indicating K-S values is greater than 0.005 , which means the data is distributed normally. A VIF values less than 10 means that multicolinearity does not occur. Further tests indicate that the Glejser test results show that none of the independent variables are statistically significant, so heteroscedastisity does not occur.
} 
Table 8. Test results of the coefficient of determination

\begin{tabular}{ccc}
\hline R Square & $\begin{array}{c}\text { Adjusted } \\
\text { R Square }\end{array}$ & $\begin{array}{c}\text { Std. error of } \\
\text { the estimate }\end{array}$ \\
\hline 0.238 & 0.226 & 2.04881 \\
\hline
\end{tabular}

From the results in Table 8 , it can be seen that the adjusted $r$ square value is 0.226 or 22.6 percent, which indicates that the whistleblowing decisions which can be explained by power distance, moral intensity and professional commitment are 22.6 percent, while 77.4 percent (100 percent - 22.6 percent) can be said to be influenced by other factors not examined in this study. According to Ahmad (2011), attitudes towards whistleblowing, organizational size, personal costs, and threats in reporting can be several examples of variables that might influence individual whistleblowing decisions. Regarding the low coefficient of determination, this can be said to be reasonable, because this research is related to human behavior, so there is a considerable variation in each observation per individual and the complexity of human behavior can also be a factor (Ghozali, 2018).

\subsection{F-test}

The F-test was carried out to find out whether all the independent variables in this study, namely power distance, moral intensity, and professional commitment simultaneously had an influence on the whistleblowing decisions of the undergraduate accounting students at FEB UGM. If the $F$ value is greater than the $F$ table value, then the research's regression model can be said to be feasible, and all the independent variables in the study can be declared to have had a simultaneous effect on the dependent variable. Table 9. presents the results of the F-test:

Table 9. F-test results

\begin{tabular}{ccc}
\hline F value & F Table & Sig. \\
\hline 19.287 & 2.65 & 0.000 \\
\hline
\end{tabular}

By looking at the results of Table 9, it is known that the calculated $F$ value is 19.287 with a significance value of 0.000 . This research's regression model can be used because it has a computed $\mathrm{F}$ value that is greater than the $\mathrm{F}$ table value, and the significant value that is owned is also smaller than 0.005 . It also means that power distance, moral intensity, and professional commitment simultaneously influenced whistleblowing decisions.

\subsection{T-test}

The research hypotheses can be accepted and a significant effect confirmed on the dependent variable if the $t$ value that is obtained is greater than the value in the $t$ table, and the probability value is smaller than the 0.05 significance level. Conversely, if the value of the $t$ count is smaller than the value in the $t$ table and the significance level is also greater than 0.05 , then the research hypotheses are rejected, and it can be concluded that, at least partially, the independent variable being tested does not have a significant effect on the dependent variable.

Table 10. Statistical test results $t$

\begin{tabular}{ccccc}
\hline \multirow{2}{*}{ No } & \multirow{2}{*}{ Variable } & \multicolumn{4}{c}{ t-test } \\
\cline { 3 - 5 } & & Unstandardized B & t & Sig. \\
\hline 1 & PD & -0.891 & $-2,962$ & 0.003 \\
2 & MI & 0.053 & 0.893 & 0.373 \\
3 & PC & 0.200 & 6.586 & 0.000 \\
\hline \multicolumn{4}{c}{ Dependent Variable: WB } \\
\multicolumn{4}{c}{ Constant $=4,024$} \\
\end{tabular}

The regression equation formulated from the results of Table 10 is as follows:

Whistleblowing decision $=4.024-0.891$ power distance +0.055 moral intensity +0.149 professional commitment $+\mathrm{e}$

This research's regression model has a constant value of 4.024 and is positive, which means that when the variables power distance, moral intensity, and professional commitment 
are consistent, the whistleblowing decision value is 4.024 .

\section{Discussion}

\subsection{Effect of power distance on whistleblowing decisions}

From Table 10, it can be seen that the power distance variable has a regression coefficient of 0.889 , which indicates that for every increase of one in the power distance variable constant, then the whistleblowing decision will decrease by 0.891. In other words, the higher the power distance, the lower the whistleblowing decision. The value of the $t$ count was 2.962 , which is also greater than the value of the $t$ table. Besides, the significance value is even smaller than 0.05 , so the conclusion derived is that the power distance variable has a significant negative effect on whistleblowing decisions and $\mathbf{H 1}$ is supported. This result is in line with the research conducted by Taylor \& Curtis(2013) who examined the impact of organizational response and power distance on the whistleblowing decisions of auditors. Power distance was also found to have a negative influence on whistleblowing decisions of auditors. Thus, auditors tend to be more courageous and do blow the whistle when the culprit is a work colleague, rather than their boss.

\subsection{Effect of moral intensity on whistleblowing decisions}

Moral intensity variables have a positive coefficient of 0.053 , so this value indicates that every increase of one in the constant of moral intensity variables, the whistleblowing decision will increase by 0.053 . This means that the higher the moral intensity of a person is, the higher the whistleblowing decision is. However, the calculated $t$ value obtained was 0.893 , which is smaller than the t table value. The significance value also exceeds 0.05 , at 0.373 . So, the conclusion is that the moral intensity variable does not have a significant effect on the whistleblowing decision, and $\mathbf{H} 2$ is not supported. This finding is also the same as the results of research conducted by Clements \& Shawver (2008) and Shawver\&Shawver (2008) who found that although accountants were able to recognize unethical situations, they tended not to blow a whistle. Thus, the moral intensity does not influence whistleblowing decisions.

\subsection{Effect of professional commitment on whistleblowing decisions}

Professional commitment variables have a regression coefficient of 0.200 so that when you add one to the constant, the whistleblowing decision will increase by 0.200 . So, it can be interpreted that the higher the professional commitment is, the higher the whistleblowing decision is. The value of the $t$ count for the professional commitment variable in Table 10 is 6.586, which is greater than the value of the $t$ table. For its significance value, it is less than 0.05 , as it is 0.00 . The conclusion that can be drawn is that professional commitment variables have a significant positive influence on whistleblowing decisions and support H3. The results of this study are also supported by research conducted by Jeffrey \& Weatherholt (1996) and Jeffrey, Weatherholt, \& Lo (1996) who found a positive relationship between professional commitment and the rules governing auditors' compliance. Taylor \& Curtis(2010)also found a positive correlation between professional commitment and auditors' intentions to conduct whistleblowing, but there was no relationship between professional commitment and reporting intention's persistence.

\section{Summary of the Hypotheses Test}

The results of the hypotheses, in review, can be seen in Table 11: 
Table 11. Summary of hypotheses test results

\begin{tabular}{llll}
\hline No. & \multicolumn{1}{c}{ Hypotheses } & Direction & \multicolumn{1}{c}{ Conclusion } \\
\hline H1 & Power distance has a negative effect on whistleblowing decision & Negative & Supported \\
H2 & Moral intensity has a positive effect on whistleblowing decision & Positive & Not Supported \\
H3 & Professional commitment has a positive effect on whistleblowing decision & Positive & Supported \\
\hline
\end{tabular}

\section{CONCLUSION AND SUGGESTION}

Research into the influence of power distance, moral intensity, and professional commitment on the whistleblowing decisions of S1 Accounting students at FEB UGM produced three main conclusions. Firstly, power distance has a significant effect, in a negative direction, on the whistleblowing decisions of S1 Accounting students at FEB UGM. Secondly, professional commitment has a significant impact, in a positive direction, on the whistleblowing decisions of S1Accounting students at FEB UGM. Thirdly, moral intensity does not affect the whistleblowing decisions of S1 Accounting students at FEB UGM.

There are limitations to this research. First, the independent variables examined in this study are only limited to power distance, moral intensity, and professional commitment. The results of the research into these three variables only explained the effect on one's whistleblowing decision by 22.6 percent. The remaining 77.4 percent of the variations cannot be explained through the independent variables examined in this study. The data collection method used in this study is through surveys with questionnaires distributed online, which limits the author as he cannot accompany the respondent in the process of filling out the questionnaire. This limitation creates the possibility of respondents misinterpreting the questions. Lastly, the respondents were only limited to undergraduate accounting students at FEB UGM, so that the results of the research into the influence of power distance, moral intensity, and professional commitment on whistleblowing decisions may be less representative of accounting students in general.

This research can be applied to both the accounting profession and accounting education. From the theoretical side, this study presents additional empirical evidence related to the influence of power distance, moral intensity, and professional commitment on whistleblowing decisions, especially for S1 Accounting students at FEB UGM. Through this research, information is presented that can be used as inputs or advice for educational practitioners, especially in the Accounting Department of FEB UGM and other universities in Indonesia, to help develop the values of integrity through a business ethics curriculum. Also, this research can increase students' knowledge and level of awareness to understand ethical issues in the accounting profession, and the importance of whistleblowing.

This research also provides inputs and suggestions for companies in implementing whistleblowing hotlines, and policies for their whistleblowing mechanisms. Also, in their recruitment processes, what things do they need to look for in potential recruits to make sure they hire employees who have high ethical values. In addition, the implication of this study in terms of policies for the education system is adding new subjects teaching morality for any level of research, to emphasize the urgency of moral intensity in any aspect.

This research also provides insight to the policymakers, such as developing whistle- 
blowing policies, particularly from the early stages of education and the pre-working stages of employment such as whistleblowing literacy programs, as well as enforcing whistleblowing channels in the working environment.

Further research is highly recommended, so it can add other independent variables that can influence individual whistleblowing decisions, such as previous organizational responses, gender, or other factors. In the process of collecting the data, it would be better if the work situation was conducive to the questionnaire, and it could be accompanied by the researcher, to reduce any confusion by the respondents which could lead to misinterpretation. Also, subsequent research can broaden the respondents to be studied to various other universities in Indonesia so that they can provide a more general picture.

\section{REFERENCE}

Albrecht, W. S., Albrecht, C. O., Albrecht, C. C., \& Zimbelman, M. F. (2012). Fraud Examination. (Jack W. Calhoun, Ed.) (4th ed.). South Western: Cengage Learning.

Aranya, N., Barak, A., \& Amernic, J. (1981). A test of Holland's theory in a population of accountants. Journal of Vocational Behavior, 19(1), 15-24. https://doi.org/10.1016/0001-8791(81) 90045-2

Aranya, N., \& Ferris, K. R. (1984). A reexamination of accountants' organizationalprofessional conflict. Accounting review, 115.

Auerbach, J. S. (1961). Progressives at sea: The La Follette act of 1915. Labor History, 2(3), 344-360. https://doi.org/10.1080/0023656610858388 2

Banda, F. L. \& M. Sholihin, M. (2012). Pengaruh penalaran moral, sikap, norma subyektif dan persepsi kontrol perilaku terhadap whistleblowing intention. Universitas Gadjah Mada. http://etd.repository.ugm.ac.id/home/detail pencarian $/ 56350$

Barnett, T., Cochran, D. S., \& Taylor, G. S. (1993). The internal disclosure policies of private-sector employers: An initial look at their relationship to employee whistleblowing. Journal of Business Ethics, 12(2), 127-136.

Beenen, G., \& Pinto, J. (2009). Resisting organizational-level corruption: An interview with Sherron Watkins. Academy of Management Learning \& Education, 8(2), 275-289.

https://doi.org/10.5465/AMLE.2009.417888 51

Bernardi, R.A., Banzhoff, C. A., Martino, A. M. and Savasta, K. J. (2011). Cheating and Whistle Blowing in the Classroom, Research on Professional Responsibility and Ethics in Accounting, 15: 165-191. https://doi.org/10.1108/S15740765(2012)0000016011

Bok, S. (1980). Whistleblowing and professional responsibilities. In Ethics teaching in higher education (pp. 277-295). Springer, Boston, MA. https://doi.org/10.1007/978-1-46133138-4 11

Bologna, J., \& Lindquist, R. J. (1995). Fraud auditing and forensic accounting: new tools and techniques. (T. W. Singleton \& A. J. Singleton, Eds.) (3rd ed.). New York: John Wiley \& Sons Inc.

Brennan, N., \& Kelly, J. (2007). A study of whistleblowing among trainee auditors. The British Accounting Review, 39(1), 61-87. https://doi.org/10.1016/j.bar.2006.12.002

Chiu, R. K. (2003). Ethical judgment and whistleblowing intention: Examining the moderating role of locus of control. Journal of business ethics, 43(1-2), 65-74. https://doi.org/10.1023/A:1022911215204

Cohen, J. R., Pant, L. W., \& Sharp, D. J. (2001). An examination of differences in ethical decision-making between Canadian business students and accounting professionals. Journal of Business Ethics, 30(4), 319- 
336.https://doi.org/10.1023/A:10107454256 75

Cooper, D. R., \& Schindler, P. S. (2014). Business research methods (12th ed.). Boston: McGraw-Hill/Irwin.

Elias, R. (2006). The Impact of Professional Commitment and Anticipatory Socialization on Accounting Students' Ethical Orientation. Journal of Business Ethics, 68, 83-90. https://doi.org/10.1007/s10551-006-9041-5

Finn, D. (1995). Ethical decision making in organizations: A management employee organization whistle-blowing model. Research on Accounting Ethics, 1, 291-313.

Ghozali, Imam. (2018). Aplikasi Analisis Multivariate dengan Program IBM SPSS25. Semarang: Badan Penerbit Universitas Diponegoro.

Goodwin, J., \& Goodwin, D. (1999). Ethical judgments across cultures: A comparison between business students from Malaysia and New Zealand. Journal of Business Ethics, 18(3), 267-281.

https://doi.org/10.1023/A:1005785020162

Graham, J. W. (1986). Principled organizational dissent: A theoretical essay. Research in organizational behavior.

Graham, J. W., Miceli, M. P., \& Near, J. P. (1992). Blowing the whistle: the organizational and legal implications for companies and employees.Administrative Science Quarterly. New York: Lexington Books. https://doi.org/10.2307/2393341

Gundlach, M. J., Douglas, S. C., \&Martinko, M. J. (2003). The decision to blow the whistle: A social information processing framework. Academy of management Review, 28(1), 107-123.

https://doi.org/10.5465/AMR.2003.8925239

Hirschman, A. O. (1970). Exit, Voice, and loyalty: responses to decline in firms, organizations. Harvard University Press. https://doi.org/10.1177/0002716271393001 54

Hofstede, G. (1993). Cultural constraints in management theories. Academy of
Management Perspectives, 7(1), 81-94. https://doi.org/10.5465/ame.1993.94091420 61

Hunt, S. D., \& Vitell, S. (1986). A general theory of marketing ethics. Journal of Macromarketing, 6(1), 5-16.

Institute of Indonesian Chartered Accountants. (2020). Kode Etik Akuntan Indonesia. Jakarta: Ikatan Akuntan Indonesia. http://www.iaiglobal.or.id/v03/files/Kode\% 20etik/

Jeffry, C., Weatherholt, N., \& Lo, S. (1996). Ethical development, professional commitment, and rule observancy attitudes: a study of auditors in Taiwan.The International Journal of Accounting, 31(3), 365-379. https://doi.org/10.1016/s00207063(96)90025-4

Jones, T. M. (1991). Ethical decision making by individuals in organizations: An issuecontingent model. Academy of management review, 16(2), 366-395.

https://doi.org/10.5465/amr.1991.4278958

Label, W. A., \& Miethe, T. D. (2011). Whistleblowing and external auditors. Journal of Applied Business Research (JABR), 15(2), 87-92.

https://doi.org/10.19030/jabr.v15i2.5682

Lee, K., Carswell, J. J., \& Allen, N. J. (2000). A meta-analytic review of occupational commitment: relations with person-and work-related variables. Journal of applied psychology, 85(5), 799.

Lord, A. T., \& DeZoort, F. T. (2001). The impact of commitment and moral reasoning on auditors' responses to social influence pressure. Accounting, Organizations and Society, 26(3), 215-235. https://doi.org/10.1016/S03613682(00)00022-2

Mesmer-Magnus, J. R., \&Viswesvaran, C. (2005). Whistleblowing in organizations: An examination of correlates of whistleblowing intentions, actions, and retaliation. Journal of business ethics, 62(3), 277-297. https://doi.org/10.1007/s10551-005-0849-1 
Miceli, M. P., \& Near, J. P. (2005). Standing up or standing by: What predicts blowing the whistle on organizational wrongdoing? Research in Personnel and Human Resources Management, 24, 95-136. https://doi.org/10.1016/S07427301(05)24003-3

Miceli, M. P., Near, J. P., \&Schwenk, C. R. (1991). Who blows the whistle and why? Ilr Review, 45(1), 113-130. https://doi.org/10.2307/2524705

Miceli, M. P., \& Near, J. P. (1984). The relationships among beliefs, organizational position, and whistle-blowing status: A discriminant analysis. Academy of Management journal, 27(4), 687-705.

Near, J. P., Rehg, M. T., Van Scotter, J. R., \& Miceli, M. P. (2004). Does type of wrong doing affect the whistle-blowing process? Business Ethics Quarterly, 14(2), 219-242. https://doi.org/10.5840/beq200414210

Polit, D. F., \& Beck, C. T. (2010). Generalization in quantitative and qualitative research: Myths and strategies. International journal of nursing studies, 47(11), 1451-1458. https://doi.org/10.1016/j.jinurstu.2010.06.00 4

Rehg, M. T., Miceli, M. P., Near, J. P., \& Van Scotter, J. R. (2008). Antecedents and outcomes of retaliation against whistleblowers: Gender differences and power relationships. Organization Science, 19(2), 221-240.

https://doi.org/10.1287/orsc.1070.0310

Sekaran, U., \& Bougie, R. (2016). Research methods for business: A skill building approach. John Wiley \& Sons.

Shawver, T. (2008). What accounting students think about whistleblowing: are future accounting professionals willing to whistle blow internally or externally for ethics violations? Management Accounting Quarterly, 9(4), 33-33.

Shawver, T. and Clements, L.H. (2008), "Whistleblowing: Factors that contribute to Management Accountants Reporting
Questionable Dilemmas", Management Accounting Quarterly, Vol. 9, No. 2, pp. 2638.https://search.proquest.com/openview/ef 6d6ce95495fbcfa37276269952f478/1?pqorigsite $=$ gscholar\&cbl $=42470 \&$ casa_token $=$ fkBSAZDHu9cAAAAA:ikNzl5TntdU1Qw Csu72xLNXLwvBie2gBmqAFh44MdFY1xocXmYYNhu0w5sP0z0VGM wD3p3EYkc

Shawver, T. A., \& Shawver, T. J. (2009). Predicting management fraud in IPO companies.ManagementAccountingQuarterl $y, 11(1), 22-26$.

Shawver, T. J., \& Shawver, T. A. (2008). Will corporate governance and whistleblowing provisions improve financial responsibility? Research on Professional Responsibility and Ethics in Accounting, 12, 123-148

Shaub M. K., Finn D. N., Munter P. (1993) The Effects of Auditor's Ethical Orientation on Commitment and Ethical Sensitivity. Behavioral Research in Accounting, 5:145169

Singer, M., Mitchell, S., \& Turner, J. (1998). Consideration of moral intensity in ethicality judgements: Its relationship with whistleblowing and need-for-cognition. Journal of Business Ethics, 17(5), 527-541.

Singleton, T. W., Singleton, A. J., Bologna, G. J., \& Lindquist, R. J. (2006). Fraud auditing and forensic accounting. John Wiley \& Sons.

Smith, A., \& Hume, E. C. (2005). Linking culture and ethics: A comparison of accountants' ethical belief systems in the individualism/collectivism and power distance contexts. Journal of Business Ethics, 62(3), 209-220. https://doi.org/10.1007/s10551-005-4773-1

Sorensen, J. E., \& Sorensen, T. L. (1974). The conflict of professionals in bureaucratic organizations. Administrative Science Quarterly, 98-106.

Taylor, E. Z., \& Curtis, M. B. (2010). An examination of the layers of workplace influences in ethical judgments: Whistle- 
blowing likelihood and perseverance in public accounting. Journal of Business Ethics, 93(1), 21-37.

https://doi.org/10.1007/s10551-009-0179-9

Taylor, E. Z., \& Curtis, M. B. (2013). Whistleblowing in audit firms: Organizational response and power distance. Behavioral Research in Accounting, 25(2), 21-43.https://doi.org/10.2308/bria-50415

Trevino, L. K., \& Victor, B. (2018). Peer reporting of unethical behavior: A social context perspective. Academy of Management journal, 35(1), 38-64. https://doi.org/10.5465/256472

Verschoor, C. C. (2008). Extraordinary circumstances: the journey of a corporate whistle-blower. internal auditing, 10(4), 381-392. https://doi.org/10.2753/pin10999922100407

Young, J. P. (2006). Whistleblowing: loyalty and dissent in the corporation. Alan F. Westin democracy, authority, and alienation in work: workers' participation in an American corporation. The Journal of Politics, 44(2), 627-628.

https://doi.org/10.2307/2130622 